\title{
Hemosiderin, a possible biomarker for sudep?
}

\author{
Hemosiderina, um possível biomarcador para sudep?
}

Hemosiderina, ¿un posible biomarcador de sudep?

\author{
Andressa Sampaio Pereira ${ }^{1}$, Patrícia de Morais Ferreira Brandão², \\ Jerónimo A. Auzmend ${ }^{3}$, Alberto Lazarowski3
}

\begin{abstract}
1.Doutoranda da Escola Paulista de Medicina da Universidade Federal de São Paulo, São Paulo-SP, Brasil. 2.Mestranda do Programa de Pós-Graduação em Ciências do Movimento da Universidade Federal do Mato Grosso do Sul, Pioneiros-MS, Brasil.

3.Universidad de Buenos Aire (UBA), Facultad de Farmacia y Bioquímica (FFyB), Instituto de Fisiopatología y Bioquímica Clínica (INFIBIOC), Ciudad Autónoma de Buenos Aires (CABA), Argentina.
\end{abstract}

\begin{abstract}
Resumo
A epilepsia é uma das doenças neurológicas de etiologia complexa que afeta em torno de 50 milhões de pessoas em todo o mundo, e é caracterizada por atividade elétrica anormal e convulsões recorrentes. As convulsões tônico-clônicas generalizadas repetitivas descontroladas (GTCS) são as principais causas de morte súbita inesperada em epilepsia (SUDEP). O estresse hipóxico induzido pela crise epiléptica resulta em disfunções neurocardiogênica, incluindo a sobrecarga de ferro a cardiomiopatia (IOC) que está relacionada à peroxidação lipídica grave causada pela produção de espécies reativas de oxigênio (ROS). A ROS induz a atividade convulsiva recorrente, favorecendo a superexpressão da glicoproteína P (P-gp) no coração. A P-gp desempenha uma função despolarizante em membranas de cardiomiócitos e os canais de potássio (Kir) controlam a excitabilidade celular quanto a repolarização do potencial de ação cardíaco. Todos esses acontecimentos resultam num possível aparecimento de bradicardia severa e arritmia fatal. Diversos estudos têm buscado evidências para diferentes possíveis biomarcadores para potencial previsão do risco de SUDEP evitando seu desfecho fatal.
\end{abstract}

Unitermos: Epilepsia, SUDEP, espécies reativas de oxigênio.

\begin{abstract}
Epilepsy is one of the neurological diseases of complex etiology that affects around 50 million people worldwide and is characterized by abnormal electrical activity and recurrent seizures. Uncontrolled generalized repetitive tonic-clonic seizures (GTCS) are the main causes of unexpected sudden death in epilepsy (SUDEP). Hypoxic stress induced by seizure results in neurocardiogenic dysfunctions, including iron overload and cardiomyopathy (IOC) which is related to severe lipid peroxidation caused by the production of reactive oxygen species (ROS). ROS induces recurrent seizure activity, favoring the overexpression of $P$ glycoprotein $(P-g p)$ in the heart. P-gp plays a depolarizing role in cardiomyocyte membranes and potassium (Kir) channels control cellular excitability regarding the repolarization of the cardiac action potential. All these events result in a possible appearance of severe bradycardia and fatal arrhythmia. Several studies have sought evidence for different possible biomarkers for potential prediction of the risk of SUDEP avoiding its fatal outcome.
\end{abstract}

Keywords: Epilepsy, SUDEP, Reactive Oxygen Species

\section{Resumen}

La epilepsia es una de las enfermedades neurológicas de etiología compleja que afecta a alrededor de 50 millones de personas en todo el mundo y se caracteriza por una actividad eléctrica anormal y convulsiones recurrentes. Las convulsiones tónico-clónicas repetitivas generalizadas no controladas (GTCS) son las principales causas de muerte súbita inesperada en la epilepsia (SUDEP). El estrés hipóxico inducido por convulsiones da como resultado disfunciones neurocardiogénicas, que incluyen sobrecarga de hierro y cardiomiopatía (IOC), que está relacionada con la peroxidación lipídica grave causada por la producción de especies reactivas de oxígeno (ROS). ROS induce una actividad convulsiva recurrente, lo que favorece 
la sobreexpresión de la glicoproteína $\mathrm{P}$ (P-gp) en el corazón. La P-gp juega un papel despolarizante en las membranas de los cardiomiocitos y los canales de potasio (Kir) controlan la excitabilidad celular con respecto a la repolarización del potencial de acción cardíaco. Todos estos eventos resultan en una posible aparición de bradicardia severa y arritmia fatal. Varios estudios han buscado evidencia de diferentes biomarcadores posibles para la predicción potencial del riesgo de SUDEP evitando su desenlace fatal.

Palabras clave. Epilepsia, SUDEP, Especies Reactivas de Oxígeno

Trabalho desenvolvido para o curso "Neurociência em Pauta" ("Neuroscience at hand"), ministrado pelo Programa de Pós-Graduação em Neurologia/Neurociências da Escola Paulista de Medicina, Unifesp, São Paulo-SP, Brasil.

\section{INTRODUCTION}

Epilepsy is a chronic neurological disorder characterized by abnormal electrical activity of the brain with a permanent predisposition to generate epileptic seizures ${ }^{1}$. According to the $\mathrm{WHO}$, the number of affected individuals is around 50 million worldwide and its impacts bring neurological, cognitive, psychological, and social damage and sequelae. It is estimated that approximately $30 \%$ of these individuals are resistant to antiepileptic drugs (AEDs), which is called refractory epilepsy $(E R)^{2}$.

In general, individuals with epilepsy are at increased risk of premature death ${ }^{2}$. Sudden and unexpected death in epilepsy (SUDEP) is characterized by sudden and unexpected death witnessed or not, excluding traumatic or drowning, without the need for evidence of seizure, where necroscopy does not identify a toxicological or anatomical reason. It is the main cause of mortality among these individuals with rates ranging from $7 \%$ to $17 \%^{3}$.

Several risk factors are associated with SUDEP, mainly the severity and frequency of generalized tonic-clonic 
seizures (GTCS). However, other factors are currently under discussion, such as early onset and duration of epilepsy, use of antiepileptic drugs (AEDs), polypharmacy and symptomatic etiology 3,4 .

Several other clinical aspects have been observed, including frequent changes in dosage and persistently low plasma levels of AEDs, in addition to low medication adherence. Such factors are commonly identified as primary risk factors not only for SUDEP, but also seen in patients with $\mathrm{ER}^{2,5}$.

The risk of SUDEP is known to increase with the severity and frequency of uncontrolled epileptic seizures, which is also common in patients with $E R$, so the risk is greater in this population. More than one mechanism appears to play a role in the development of SUDEP, but its specific mechanical cause has not yet been identified ${ }^{5}$.

Several studies in the literature suggest that SUDEP may be related to cardiogenic origin and that they occur in the ictal and interictal periods. ECG and ECG tests performed during episodes of seizures identified an increase in heart rate that preceded the clinical and electrographic onset of the episodes. On the other hand, involvement of the parasympathetic system identified by sinus bradycardia was also observed, possibly due to apnea during crises ${ }^{6,7}$.

Other lines of research point to terminal cardiac arrhythmia due to hypoxic stress triggered by frequent seizures associated with sympathetic overstimulation that leads to neurocardiogenic injury compromising the electrical 
properties of the myocardium, resulting in severe bradycardia and fatal cardiac arrhythmia ${ }^{6,7}$.

Despite the close relationship between the severity of ER and the risk of SUDEP and the biomolecular information available that elucidate the diversity of mechanisms in ER, there are no adequate biomarkers to predict the risk of SUDEP to the point of avoiding the fatal outcome. For now, electrocardiograms, electroencephalograms and imaging studies are used as the only clinically relevant biomarkers available, however, they do not clarify the molecular cause that produces them and, therefore, it is not possible to use them for an effectively preventive approach ${ }^{5}$.

\section{Ferroptosis and iron metabolism in epilepsy}

Much has been said about the various forms of cell death that are involved in the pathogenesis of diseases ${ }^{8}$. The physiological process of cell death is related to the development, aging and homeostasis of tissues, which is sometimes deregulated in various pathological conditions ${ }^{9}$. There are some types of programmed cell death that are apoptosis, necrosis, autophagy, and necrotic apoptosis, each with its specific physiological and biological characteristics. Currently, a new mode of cell death known as ferroptosis has been identified ${ }^{10}$.

Ferroptosis is a new mode of regulated cell death, which is related to severe lipid peroxidation caused by the production of reactive species of oxygen to lipids (ROS) and iron overload, present in several neurological diseases, 
including epilepsy ${ }^{11}$. It is morphologically distinguished from other modes of cell death mainly by shrinking mitochondria and reducing or disappearing mitochondrial ridges ${ }^{10}$.

The first compounds cited as inducing non-apoptotic ferroptosis were erastine and RSL3, both of which have a similar mechanism of cell death. Erastin induces the generation of ROS that is directly involved in the cell death process and promotes the inhibition of the Xc- system, inducing the onset of ferroptosis ${ }^{12}$.

Ferroptosis involves the abnormal metabolism of lipids, glutathione (GSH) and iron. Lipid metabolism has two metabolic enzymes ACSL4 and LPCAT3, which undergo oxidation and lead to ferroptosis. It is worth mentioning that the GPX4-GSH-cysteine axis depends on itself and the FSP1ubiquinone (CoQ10) -NAD (P) H pathway, which are also associated with lipid peroxidation and also ferroptotic cell death ${ }^{13}$.

The trace element essential to life, iron, is indispensable in the mechanisms of ferroptosis, however, the use of iron chelators can be useful in the treatment of diseases ${ }^{13}$, since they act ascell death inhibitors when treated with RSL $3^{12}$. In addition, iron is involved in human growth and development, and its compounds act on the nervous system in the formation of myelin, in the metabolism of catecholamine neurotransmitters, in intellectual development and also in neurodegenerative diseases ${ }^{14}$.

When brain injury or hemorrhagic cortical infarction occurs, red blood cells and hemoglobin overflow from the 
blood, allowing the release of iron and the appearance of ROS and reactive nitrogen species (RNS) ${ }^{14}$. The degradation of hemoglobin favors the deposit of hemosiderin, which is related to neurological disorders, and is one of the main forms of iron storage in the human body ${ }^{15}$.

Oxidative stress (EO) involves ROS, RNS and even reactive lipid species (RLS), inducing lipid peroxidation and cellular damage that leads to overexpression of miR155 and induces the availability of free iron. EO is also closely related to the coexistence of neuroinflammatory markers (TLR4, COX2 and NF-KB) and EO markers (xCT, iNOS) ${ }^{16}$. Thus, iron can trigger the development of inflammation in the epileptic brain $^{13}$.

This occurs due to the excessive production of $\mathrm{RO}$, causing cytotoxicity, however, low concentrations of ROS have a protective role in cells regarding bacterial damage by intracellular signaling molecules ${ }^{14}$. Thus, cells and systems seek to control iron homeostasis, in order to avoid iron overload and consequent cytotoxicity ${ }^{17}$. The dysregulation of iron metabolism and the activation of antioxidant signals may be involved with focal dysplasia type IIb and tuberous sclerosis ${ }^{18}$.

High levels of ROS and oxidative stress are seen after an epileptic seizure, and at the time of the seizures a high level of extracellular glutamate is seen, these events favor recurrent seizures, further aggravating nerve damage. In addition, the high level of extracellular glutamate promotes epileptic seizures and status epilepticus $(\mathrm{SE})^{14}$, which is 
defined asseizure activity of 5 minutes or more continuous electrographic, or recurrent seizure activity without recovery between seizures ${ }^{19}$.

\section{Epileptic heart}

Adequate energy supply is essential for the functioning of the brain and heart. The literature illustrates that the "epileptic heart" is a heart with damaged coronary vasculature resulting from repeated hypoxic stress, causing mechanical and electrical cardiac dysfunction and the presence of increased catecholamines. This concept emerged after observations of cardiac changes in patients with chronic and drug-resistant epilepsy ${ }^{20}$.

Acute and chronic epileptic seizures usually cause cardiac ischemia, changes in cardiac variability, increased heart rate or severe bradycardia, ST-segment depression and the presence of cardiac fibrosis ${ }^{20}$. In addition, repetitive seizure activity leads to overexpression of $\mathrm{P}$-gp in the heart and this results in a predisposition to SUDEP and as a result of hypoxia, simultaneously, loss of Kir expression in cardiomyocytes ${ }^{21}$.

SUDEP may be related to heart failure due to high hypoxic stress and sympathetic over-stimulation that results in neurocardiogenic injury, since it affects the electrical properties of the heart, this favors the possible appearance of severe bradycardia and fatal arrhythmia ${ }^{20}$. In addition, the sequence of events arising from hypoxia induces neurotoxicity through over-stimulation of glutamate 
receptors, the accumulation of intracellular sodium and calcium cells, mitochondrial damage, and neuronal death ${ }^{21}$.

The subsequent response to this stress is the activation of hypoxia-inducible factor 1 (HIF1), which is involved in cellular homeostasis, with its targets directed at vasomotor control, angiogenesis, erythropoiesis, iron metabolism and cell death ${ }^{21}$ and regulation positive expression of responsive genes such as P-gp and erythropoietin EPO receptor ${ }^{22}$.

Hypoxic stress stimulates the appearance of $p$ glycoprotein ( $\mathrm{P}-\mathrm{gp}$ ) expression, which plays a depolarizing function in cardiomyocyte membranes, despite its pharmacoresistant property. Potassium channels (Kir) are also associated with epilepsy and cardiac dysfunction and their function is to control cellular excitability regarding the repolarization of the cardiac action potential ${ }^{20}$. The Kir channels carry $\mathrm{K}+$ ions and control cellular excitability, the dysfunction of the Kir channels is one of the triggering reasons for epileptic seizures, since they can be the cause of cardiac pathology or even SUDEP due to extracellular potassium concentration ${ }^{22}$.

Regarding P-gp, it is important to highlight that, in general, it is absent in neurons and cardiomyocytes, however, P-gp expressions can also modify the resting membrane, producing depolarization ${ }^{20}$. It is worth mentioning that hypoxia will also increase the expression of the transferrin receptor (Tfr-R), through which more iron will enter the cell, resulting in several structural damages and functional changes ${ }^{23}$. 
Convulsive/hypoxic stress commonly promotes an oxidative tissue environment with formation of ROS associated with free $\mathrm{Fe}+2$ via Haber-Weiss and Fenton reactions. Ferroptosis is one of the main mechanisms of cell death. Thus, oxidative stress is an important factor in Iron Overload Cardiomyopathy (IOC), since the accumulation of iron in the myocardium can result in cardiac dysfunction ${ }^{23}$.

It is important to note that chronic epilepsy is associated with changes in cardiac electrophysiology that can lead to the development of arrhythmias, bradycardia, and asystole $^{24}$. It is observed that the increase in the sodium current or the inhibition of the potassium current at the moment of the ventricular action potential plateau, causes an extension of the action potential duration, causing a greater prolongation of the QT interval, showing that ventricular arrhythmias can be triggered by the presence of early depolarizations resulting from the stretching of the action potential plateau ${ }^{25}$.

\section{SUDEP Biomarkers}

As previously seen, the cause of SUDEP is still unknown, however, several possible causes and relationships have been studied and investigated, among them cardiovascular changes are suggested as the most common mechanisms. Convulsive stress leads the heart muscle cells to hypoxic conditions, activating the HIF-1a factor and overexpression of P-gp and erythropoietin (EPO) ${ }^{5}$. 
Despite the diversity of studies, there is still no reliable biomarker and, therefore, prevention strategies are basically based on clinical findings and on imaging, electrocardiogram, and electroencephalogram exams.

Among the possible biomarkers studied for risk stratification, microRNAs (miRNAs) stand out. One study identified that among a miRNA panel only miR-301a-3p was regulated positively in both the hippocampus and the plasma $^{8}$. Another study reported the detection of 22 miRNAs, including miR-301a-3p, in the plasma of patients with heart failure, which corroborates the bets on miRNAs as a possible biomarker for SUDEP5,26.

Other studies have also proposed that the accumulation of iron in the heart could be associated with terminal cardiac arrhythmia and the development of SUDEP status, indicating hypoxic-ischemic damage, thus inducing hemosiderin accumulation as in the $\mathrm{IOC}^{6}$.

Since the accumulation of iron in tissues can be detected by non-invasive imaging methods, iron overload in the heart can assist in the identification of cardiac injury as a risk biomarker for SUDEP.

Finally, a last study pointed out that the cardiac fatty acid-binding protein (H-FABP) that is released from cardiomyocytes after an ischemic episode ${ }^{27}$, can also be a sensitive and early biomarker for myocardial infarction, since it is twenty times more specific to the heart muscle than myoglobin. Therefore, H-FABP could be used as an early diagnosis tool for myocardial infarction ${ }^{16}$. 


\section{CONCLUSION}

SUDEP in epilepsy is a complex phenomenon that has been related to several risk factors. The hypoxic stress induced by the seizure promotes the overexpression of $\mathrm{P}$-gp and consequent changes in the electrical potential leading to depolarization of the membrane. P-gp plays a depolarizing role in cardiomyocyte membranes and Kir control cellular excitability through repolarization of the cardiac action potential. This complex mechanism develops in the heart after seizure/hypoxic stress. IOC related to iron metabolism, induces hemosiderin deposits resulting in the appearance of fatal cardiac arrhythmia. In addition, several studies have sought evidence for different possible biomarkers to potentially predict the risk of SUDEP avoiding its fatal outcome.

\section{REFERENCES}

1.Fisher RS, Boas WVE, Blume W, Elger C, Genton P, Lee P, et al. Epileptic Seizures and Epilepsy: Definitions Proposed by the International League Against Epilepsy (ILAE) and the International Bureau for Epilepsy (IBE). Epilepsia 2005;46:470-2. https://doi.org/10.1111/j.0013-9580.2005.66104.x

2.Taborda F, Rocha L, Enrique A, Goicoechea S, Casta R, Orozco S, et al. New model of pharmacoresistant seizures induced by 3mercaptopropionic acid in mice. Epilepsy Res 2017;129:8-16. https://doi.org/10.1016/j.eplepsyres.2016.10.012

3.Scorza F, Tucci PJF. Sudden Death in Brazil: Epilepsy Should be in Horizon. Arq Bras Cardiol 2015;105:197-8. https://doi.org/10.5935/abc.20150072

4.Sveinsson O, Andersson T, Mattsson P, Carlsson S. Clinical risk factors in SUDEP. Neurology 2020;94:e419-29. https://doi.org/10.1212/WNL.0000000000008741

5.Auzmendi J, Akyuz E, Lazarowski A. The role of P-glycoprotein (Pgp) and inwardly rectifying potassium (Kir) channels in sudden unexpected death in epilepsy (SUDEP). Epilepsy Behav 
2019;121:106590. https://doi.org/10.1016/j.yebeh.2019.106590

6.Akyuz E, Doganyigit Z, Eroglu E, Moscovicz F, Merelli A. Myocardial Iron Overload in an Experimental Model of Sudden Unexpected Death in Epilepsy Front Neurol 2021;12:1-9. https://doi.org/10.3389/fneur.2021.609236

7.Scorza FA, Arida RM, Albuquerque M, Cavalheiro EA. Sudden death in epilepsy: All roads lead to the heart. Rev Ass Med Bras 2008;54:199200. https://doi.org/10.1590/s0104-42302008000300008

8. Wu X, Li Y, Zhang S, Zhou X. Ferroptosis as a novel therapeutic target for cardiovascular disease. Theranostics 2021;11:3052-9. https://doi.org/10.7150/thno.54113

9. Fang X, Wang H, Han D, Xie E, Yang X, Wei J, et al. Ferroptosis as a target of protection against cardiomyopathy. Proc Nat Acad Sci 2019;116:2672-80. https://doi.org/10.1073/pnas.1821022116

10.Li J, Cao F, Yin HI, Huang Z, Lin Z, Mao N, et al. Ferroptosis: past, present and future. Cell Death Dis 2020;11:88. https://doi.org/10.1038/s41419-020-2298-2

11.Kahn-Kirby A, Amagata A, Maeder C, Mei J, Sideris S, Kosaka Y, et al. Targeting ferroptosis: a novel therapeutic strategy for the treatment of mitochondrial disease-related epilepsy. PLoSOne 2019;14:e0214250. https://doi.org/10.1371/journal.pone.0214250 12.Yang WS, Stockwell BR. Ferroptosis: Death by Lipid Peroxidation. Trends Cell Biol 2016;26:165-76. https://doi.org/10.1016/j.tcb.2015.10.014

13. Shen $L$, Lin $D$, Li X, Wu H, Lenahan C, Pan $Y$, et al. Ferroptosis in Acute Central Nervous System Injuries: The Future Direction? Front Cell Develop Biol 2020;8:594. https://doi.org/10.3389/fcell.2020.00594

14.Shuang C, Yongmin C, Yukang Z, Xi K, Yan L, Meiwen G, et al. Iron Metabolism and Ferroptosis in Epilepsy. Front Neurosci 2020;14:1-16. https://doi.org/10.3389/fnins.2020.601193

15.Zhang L, Zou X, Zhang B, Cui L, Zhang J, Mao Y, et al. Label-free imaging of hemoglobin degradation and hemosiderin formation in brain tissues with femtosecond pump-probe microscopy. Theranostics 2018;8:4129-40. https://doi.org/10.7150/thno.26946

16. Li Y, Thom M, Jacques TS. Novel therapeutic targets in epilepsy: oxidative stress and iron metabolism. Neuropathol App Neurobiol 2020;46:519-21. https://doi.org/10.1111/nan.12615

17.Piperno A, Pelucchi S, Mariani R. Inherited iron overload disorders. Transl Gastroenterol Hepatol 2020;5:25. https://doi.org/10.21037/tgh.2019.11.15

18.Zimmer T, Ciriminna G, Arena A, Anink J, Korotkov A, Jansen F. Chronic activation of anti-oxidant pathways and iron accumulation in epileptogenic malformations. Neuropathol Appl Neurobiol 2020;46:546-63. https://doi.org/10.1111/nan.12596

19.Peng P, Peng J, Yin F, Deng X, Chen C, He F, et al. Ketogenic Diet as a Treatment for Super-Refractory Status Epilepticus in Febrile Infection-Related Epilepsy Syndrome. Front Neurol 2019;10:423. https://doi.org/10.3389/fneur.2019.00423 
20.Auzmendi J, Lazarowski A. Seizures Induces Hypoxia and Hypoxia Induces Seizures. A Perverse Relationship that Increases the Risk of SUDEP. Neurol Dis Epilepsy J 2020;3:135. http://hdl.handle.net/11336/134927

21. Marelli A, Czornyj L, Rocha L, Lazarowski A. Erythropoietin as Potential Neuroprotective and Antiepileptogenic Agent in Epilepsy and Refractory Epilepsy. In: Talevi A, Rocha L (eds). Antiepileptic Drug Discovery. Methods in Pharmacology and Toxicology. New York: Humana Press; 2016; p147-61. https://doi.org/10.1007/978-1-4939$6355-3 \quad 8$

22. Auzmendi J, Akyuz E, Lazarowski A. The role of P-glycoprotein (Pgp) and inwardly rectifying potassium (Kir) channels in sudden unexpected death in epilepsy (SUDEP). Epilepsy Behav 2019;121:106590. https://doi.org/10.1016/j.yebeh.2019.106590

23.Doganyigit Z, Eroglu E, Moscovicz F, Merelli A, Lazarowski A, Auzmendi J. Myocardial Iron Overload in an Experimental Model of Sudden Unexpected Death in Epilepsy. Front Neurol 2021;12:4. https://doi.org/10.3389/fneur.2021.609236

24.Bleakley LE, Soh MS, Bagnall RD, Sadleir LG, Gooley S, Semsarian $\mathrm{C}$, et al. Are Variants Causing Cardiac Arrhythmia Risk Factors in Sudden Unexpected Death in Epilepsy? Front Neurol 2020;11:925. https://doi.org/10.3389/fneur.2020.00925

25.Ravindran K, Powell KL, Todaro M, O'Brien TJ. The pathophysiology of cardiac dysfunction in epilepsy. Epilepsy Res 2016;127:19-29. https://doi.org/10.1016/j.eplepsyres.2016.08.007

26. Matteis M, Cecchetto G, Munari G, Balsamo L, Gardiman MP, Giordano $\mathrm{R}$, et al. Circulating miRNAs expression profiling in drugresistant epilepsy: Up-regulation of miR-301a-3p in a case of sudden unexpected death. Leg Med 2018;31:7-9. https://doi.org/10.1016/j.legalmed.2017.12.003

27.El Shorbagy HH, Elsayed MA, Kamal NM, Azab AA, Bassiouny MM, Ghoneim IA. Heart-type fatty acid-binding protein as a predictor of cardiac ischemia in intractable seizures in children. J Pediatr Neurosci 2016;11:175-81. https://doi.org/10.4103/1817-1745.193364 